\title{
INFLUENCE OF PHYSICAL ENVIRONMENT OF RESIDENTIAL TO TRANSMISSION OF PULMONARY TUBERCULOSIS IN BARITO SELATAN REGENCY
}

\author{
Anita Aprilisa ${ }^{1}$, Emmy Sri Mahreda $^{2}$, Kissinger $^{2}$ and Fatmawati ${ }^{2}$ \\ ${ }^{1}$ Master of Natural Resource and Environmental Management Study Program \\ ${ }^{2}$ Faculty of Fisheries, Lambung Mangkurat University \\ http://doi.org/10.35410/IJAEB.2019.4440
}

\begin{abstract}
This study aims to analyze the physical environment of the home in people affected by pulmonary tuberculosis and who are not affected by pulmonary tuberculosis, to determine the effect of the physical condition of housing the physical environment of the home in people affected by pulmonary tuberculosis. The research method used in this study is a survey method. Based on the research, it is known that the influence of the physical condition of housing on patients with pulmonary tuberculosis that for the lighting variable is part of the homes of lung tuberculosis patients who do not meet the requirements $(89.86 \%)$, as well as ventilation $(98.6 \%)$, humidity (91.3\%) and occupancy density meets the requirements (52.2\%). Houses with tuberculosis are eligible for variable lighting $(10.14 \%)$, ventilation $(0 \%)$, humidity $(8.70 \%)$ and occupant density (47.8\%). Effect of Physical Condition of Housing on Non-Sufferers of Lung Tuberculosis. For lighting variables in the control house (non-pulmonary TB sufferers) that did not meet the requirements $(27.54 \%)$, ventilation (100\%), humidity $(57.97 \%)$ and occupancy density $(18.84 \%)$. Whereas in the control house that meets the requirements for lighting $(72.46 \%)$, ventilation $(0.00 \%)$, humidity $(42.03 \%)$, and occupant density $(81.16 \%)$. The physical environment of the housing of pulmonary tuberculosis sufferers in South Barito Regency does not generally meet the requirements of good lighting, ventilation, humidity and density of residents in the house. The physical environment that is not sufferers for lighting and density of occupants is more qualified, but for ventilation and humidity is still dominant that does not meet the requirements. There is a significant influence on the level of $90 \%$ of the physical condition of the house from lighting and humidity conditions as well as the density of its inhabitants to patients with pulmonary tuberculosis in Barito Selatan Regency, while to control (non-sufferers) pulmonary tuberculosis, the humidity and occupant density variables have a significant effect after controlling the research variables.
\end{abstract}

Keywords: housing, lighting, humidity, ventilation, density, tuberculosis

\section{INTRODUCTION}

Lung tuberculosis (pulmonary tuberculosis) is a disease that has long been a major public health challenge in the world and is still a major health problem in developing countries. One third of the world population is infected by Mycobacterium tuberculosis and is still a global health problem, where most of the sufferers of Tuberculosis are of productive age (15-55 years). This 
causes poor health among millions of people each year and becomes the second leading cause of death from infectious diseases throughout the world, after the Human Immunodeficiency Virus (HIV) / AIDS (Acquired Immune Deficiency Syndrome) (Kemenkes, 2010).

Transmission of this disease through the mediation of saliva or sputum of patients containing tuberculosis bacilli. Saliva flew with air and was sucked by healthy people, entered the lungs and caused lung tuberculosis. Deaths caused by TB disease in Central Kalimantan in 2016 were 74 men and 54 women, 2017 as many as 77 men and 61 women (SITB Provincial Health Office, Kalteng Province, 2017). In South Barito District there were 2 deaths due to TB in 2016 and 2 in 2017 and 2 in 2018 (2 TB Wasor of the Barsel District Health Office, 2018).

The TB eradication program in Central Kalimantan is implemented in accordance with the DOTS (directly observed treatment shortcourse) strategy, which is a strategy for controlling TB disease through short-term treatment with direct supervision. The national P2 Pulmonary TB Guideline Policy, TB case finding in the form of passive case pending, is aimed at groups of TB affected populations and vulnerable populations with active promotion by health workers together with the community (Kemenkes 2014).

This study aims to analyze the physical environment of the home in people affected by pulmonary tuberculosis and who are not affected by pulmonary tuberculosis, to determine the effect of the physical condition of housing the physical environment of the home in people affected by pulmonary TB. The research method used in this study is a survey method.

\section{RESEARCH METHODS}

This research was conducted at the homes of people with tuberculosis / Tuberculosis disease and homes of non-tuberculosis patients in the working area of health centers in the South Barito Regency (positive for tuberculosis and control homes / non-sufferers). Sampling was carried out by purposive sampling with the consideration that the transmission of pulmonary tuberculosis in the South Barito District has increased every year and the physical condition of the house / dwelling that still does not meet the requirements as well as its area which is not in the lowlands, flat and hilly, so that recommendations towards communities in the South Barito Regency. The research sample houses 69 houses from 206 cases of the study population in the work area of 6 Districts with 12 Puskesmas in Barito Selatan District.

Data on the measurement results of the characteristics of pulmonary TB respondents and the physical condition of the house as well as the results of interviews with respondents were collected, then will be analyzed descriptively, this is to answer the first goal. Next to answer the second goal, which is to answer the purpose of knowing the effect between lighting, ventilation, humidity as well as residential density with the incidence of pulmonary TB disease used multivariate logistic regression analysis, because the dependent variable is a dichotomic categorical variable (Sopiyudin Dahlan, 2001).

The equation model that will be obtained is: 
$\ln \left(\frac{p}{1-p}\right)=\beta_{0}+\beta_{1} \cdot x_{1}+\beta_{2} \cdot x_{2}+\beta_{3} \cdot x_{3}+\beta_{4} \cdot x_{4}+\varepsilon$

Where :

$\beta_{0}=$ constant which is commonly called intercept

$\beta_{1}=$ regression coefficient of the lighting variable

$\beta_{2}=$ ventilation variable regression coefficient

$\beta_{3}=$ regression coefficient of humidity variable

$\beta_{4}=$ regression coefficient of the occupant density variable

$\chi_{1}=$ lighting variable (dichotomy)

$\chi_{2}=$ ventilation variable (dichotomy)

$\chi_{3}=$ lighting variable (dichotomy)

$\chi_{4}=$ occupant density variable (dichotomy)

$\rho=$ probability of occurrence of pulmonary tuberculosis (pulmonary tuberculosis)

$\varepsilon=$ error

\section{RESULTS AND DISCUSSION}

Results of Measurement of Physical Condition of Respondents' Houses in South Barito District

Table 1. Recapitulation of the measurement results of the respondent's physical condition

\begin{tabular}{|c|c|c|c|c|c|c|c|c|c|}
\hline \multirow{5}{*}{ No } & \multirow{5}{*}{$\begin{array}{c}\text { The type of } \\
\text { disease }\end{array}$} & \multicolumn{8}{|c|}{ Variable Physical Condition Home } \\
\hline & & \multicolumn{2}{|c|}{ Lighting } & \multicolumn{2}{|c|}{ Ventilation } & \multicolumn{2}{|c|}{ Humidity } & \multicolumn{2}{|c|}{ Occupancy Density } \\
\hline & & \multicolumn{2}{|c|}{$\left(\mathrm{X}_{1}\right)$} & \multicolumn{2}{|c|}{$\left(\mathrm{X}_{2}\right)$} & \multicolumn{2}{|c|}{$\left(X_{3}\right)$} & \multicolumn{2}{|c|}{$\left(\mathrm{X}_{4}\right)$} \\
\hline & & $\begin{array}{c}<60 \text { Lux } \\
\text { atau }>120 \\
\text { Lux }\end{array}$ & $\begin{array}{c}60-120 \\
\text { Lux }\end{array}$ & $\begin{array}{c}<10 \% \\
\text { floor } \\
\text { area of } \\
\text { the } \\
\text { house }\end{array}$ & $\begin{array}{l}>10 \% \\
\text { floor } \\
\text { area of } \\
\text { the } \\
\text { house }\end{array}$ & $\begin{array}{c}<40 \% \text { atau } \\
>60 \%\end{array}$ & $40 \%-60 \%$ & $\begin{array}{c}<4 \\
\mathrm{~m}^{2} / \text { Orang }\end{array}$ & $\begin{array}{c}>4 \\
\mathrm{~m}^{2} / \text { Orang }\end{array}$ \\
\hline & & (TMS) & (MS) & (TMS) & (MS) & (TMS) & (MS) & (TMS) & (MS) \\
\hline 1 & $\begin{array}{l}\text { Home for Lung } \\
\text { TB Patients }\end{array}$ & 62 & 7 & 68 & 1 & 63 & 6 & 36 & 33 \\
\hline
\end{tabular}


International Journal of Agriculture, Environment and Bioresearch

Vol. 4, No. 05; 2019

ISSN: $2456-8643$

\begin{tabular}{|c|l|c|c|c|c|c|c|c|c|} 
& (Resp.) & & & & & & & & \\
& Percentage (\%) & 89,86 & 10,14 & 98,55 & 1,45 & 91,30 & 8,70 & 52,17 & 47,83 \\
\hline \multirow{2}{*}{2} & $\begin{array}{l}\text { Lung TB Patient } \\
\text { Non-Home } \\
\text { (control) (Resp.) }\end{array}$ & 19 & 50 & 69 & 0 & 29 & 40 & 13 & 56 \\
\cline { 2 - 9 } & Percentage (\%) & 27,54 & 72,46 & 100,00 & 0,00 & 42,03 & 57,97 & 18,84 & 81,16 \\
\hline \multirow{2}{*}{} & TOTAL (Resp.) & 81 & 57 & 137 & 1 & 92 & 46 & 49 & 89 \\
\cline { 2 - 9 } & Percentage (\%) & 58,70 & 41,30 & 99,28 & 0,72 & 66,67 & 33,33 & 35,51 & 64,49 \\
\hline
\end{tabular}

Note: TMS = Not Eligible, MS = Eligible.

The lighting variables of some houses that did not meet the criteria for lung tuberculosis $(89.86 \%)$, as well as ventilation $(98.6 \%)$, humidity $(91.3 \%)$ and occupancy density were eligible (52.2\%). lighting in control houses (non-pulmonary tuberculosis patients) that did not meet the requirements $(27.54 \%)$, ventilation $(100 \%)$, humidity (42.03\%) and occupancy density (18.84\%).

\section{Effect of Physical Conditions on Home Patients with Pulmonary Tuberculosis}

The results of the study prove that the physical environment of the home can influence the high incidence of pulmonary tuberculosis. In addition to the home environment that influences tuberculosis events, the physical, biological and social environment conditions will also be detrimental to health and can affect tuberculosis disease and ultimately affect the high incidence of tuberculosis (Muaz, 2014).

A house is said to be healthy if it fulfills the four basic requirements, among others: fulfilling physiological needs such as lighting, disposition, sufficient space and avoiding disturbing noise, meeting psychological needs such as adequate "privacy" and good communication between occupants, meeting the requirements for preventing infectious diseases including clean air supply, disposal of domestic wastewater and wastewater, free from disease vectors, excessive dwelling density, adequate sunlight, protected food and drinks and adequate pollution and lighting and fulfillment and meet the requirements for prevention of accidents both from inside and outside the home (Indonesian Minister of Health Decree No. 829, 1999).

The OR (Odds Ratio) value for the lighting variable is 8.405 , humidity is 8.097 and occupant density is 4.533. So that it is said that the effect of lighting, humidity and density of occupants in homes that do not meet the requirements can have an effect on the occurrence of pulmonary tuberculosis which is 8,839 times, 7,144 times and 4,354 times greater than houses that have lighting, humidity and density of occupants fulfilling the requirements.

Effect of Physical Condition of Housing on Non-People with Pulmonary Tuberculosis (Control) 
The results of the non-logistic regression logistic statistical tests for pulmonary tuberculosis (control) are presented in Table 2 below:

Table2. Logistic regression of lighting, ventilation, humidity and occupancy density variables for non-pulmonary tuberculosis sufferers (Control)

\begin{tabular}{|c|c|c|c|c|c|c|c|c|c|}
\hline & & \multicolumn{8}{|c|}{ Variables in the Equation } \\
\hline & & \multirow[t]{2}{*}{ B } & \multirow[t]{2}{*}{ S.E. } & \multirow[t]{2}{*}{ Wald } & \multirow[t]{2}{*}{$d f$} & \multirow[t]{2}{*}{ Sig. } & \multirow[t]{2}{*}{$\operatorname{Exp}(B)$} & \multicolumn{2}{|c|}{$\begin{array}{c}95 \% \text { C.I.for } \\
\operatorname{EXP}(B)\end{array}$} \\
\hline & & & & & & & & Lower & Upper \\
\hline & $\mathrm{X} 1 . \mathrm{k}$ & $-3,017$ & 1,543 & 3,825 & 1 &, 051 & ,049 & ,002 & \\
\hline & $\mathrm{X} 2 . \mathrm{k}$ & 2,590 & 1,385 & 3,497 & 1 &, 061 & 13,325 & ,883 & 201,096 \\
\hline \multirow[t]{3}{*}{ Step $1^{\mathrm{a}}$} & X3.k & 3,628 & 1,433 & 6,409 & 1 & ,011 & 37,631 & 2,269 & 624,204 \\
\hline & $\mathrm{X} 4 . \mathrm{k}$ & $-3,790$ & 1,320 & 8,245 & 1 &, 004 & 023 &, 002 &, 300 \\
\hline & Constant &,- 142 & 667 & 045 & 1 & ,831 & ,868 & & \\
\hline
\end{tabular}

a. Variable(s) entered on step 1: X1.k, X2.k, X3.k, X4.k.

Description: $\mathrm{X}_{1}=$ Lighting

$\mathrm{X}_{2}=$ Ventilation

$\mathrm{X}_{3}=$ Humidity

$\mathrm{X}_{4}=$ Occupant Density

Table 2. shows that the p-value of the lighting variable is 0.051 , ventilation is 0.061 , humidity is 0.011 and occupant density is 0.004 , which means that without controlling the influence of other research variables, there is a significant influence of lighting, humidity and occupant density on the house non patients with pulmonary tuberculosis (control) at the level of significance $(\alpha)$ of 0.05 . While the ventilation variable significantly affected non-patients with pulmonary tuberculosis (control) at a significant level of $61 \%(0.061)$.

When seen from the p-value of the variable above, then the model must proceed to step 2 so that the results obtained as in table 3 . 
Table 3. Logistic regression of lighting, humidity and occupancy density variables for nonsufferers of pulmonary tuberculosis (Control)

Variables in the Equation

\begin{tabular}{|rr|r|r|r|r|r|r|r|r|}
\hline & & \multicolumn{1}{|c|}{ B } & S.E. & Wald & df & Sig. & Exp(B) & \multicolumn{2}{|c|}{$95 \%$ C.I.for EXP(B) } \\
\cline { 7 - 9 } & & & & & & & & \multicolumn{1}{c|}{ Lower } & \multicolumn{1}{c|}{ Upper } \\
\hline X1.k & $-1,923$ & 1,175 & 2,679 & 1 &, 102 &, 146 &, 015 & 1,462 \\
Step 1 b & X3.k & 3,355 & 1,292 & 6,750 & 1 &, 009 & 28,656 & 2,280 & 360,214 \\
& X4.k & $-3,498$ & 1,176 & 8,850 & 1 &, 003 &, 030 &, 003 &, 303 \\
& Constant &, 216 &, 613 &, 125 & 1 &, 724 & 1,242 & & \\
\hline
\end{tabular}

a. Variable(s) entered on step 1: X1.k, X3.k, X4.k.

$$
\text { Information: } \begin{aligned}
\mathrm{X}_{1} & =\text { Lighting } \\
\mathrm{X}_{3} & =\text { Moisture } \\
\mathrm{X}_{4} & =\text { Occupant Density }
\end{aligned}
$$

Table 3 above shows that after removing the ventilation variable (X2) from the model, the pvalue of the lighting variable is obtained by 0.102 ; humidity of 0.009 ; and occupant density is 0.003 which means that without controlling the influence of other research variables, there is a statistically significant effect of humidity and occupant density in the home on non-pulmonary TB patients (control) at the significance level $(\alpha)$ of 0.05 . While the lighting variable no significant effect on non-patients with pulmonary tuberculosis (control).

When seen from the p-value of the variable above, the model must be continued to step 3 by removing the lighting variable. Then a new model is obtained as follows:

Table 4. Logistic regression of humidity and occupancy density variables for non-patients with pulmonary tuberculosis (Control)

\section{Variables in the Equation}




\begin{tabular}{|c|c|c|c|c|c|c|c|c|c|}
\hline & \multirow[t]{2}{*}{ B } & \multirow[t]{2}{*}{ S.E. } & \multirow[t]{2}{*}{ Wald } & \multirow[t]{2}{*}{ df } & \multirow[t]{2}{*}{ Sig. } & \multirow[t]{2}{*}{$\operatorname{Exp}(\mathrm{B})$} & \multicolumn{2}{|c|}{ 95\% C.I.for EXP(B) } \\
\hline & & & & & & & & Lower & Upper \\
\hline \multirow{3}{*}{ Step $1^{c}$} & X3.k & 3,339 & 1,247 & 7,173 & 1 & ,007 & 28,200 & 2,449 & 324,759 \\
\hline & X4.k & $-3,696$ & 1,154 & 10,265 & 1 & 001 & ,025 & 003 & 238 \\
\hline & Constant &,- 154 & ,556 & ,077 & 1 & 782 & ,857 & & \\
\hline
\end{tabular}

a. Variable(s) entered on step 1: X3.k, X4.k.

Information :

$\mathrm{X}_{3}=$ Humidity

$\mathrm{X}_{4}=$ Occupant Density

The table above shows that after removing the ventilation variables (X2) and Lighting (X1) from the model, the p-value of the humidity variable is obtained by 0.007 ; and occupant density is 0.001 which means that without controlling the influence of other research variables, there is a statistically significant effect of humidity and occupant density in the home on Non-pulmonary tuberculosis (control) patients at the significance level $(\alpha)$ of 0.05 .

The OR value for the humidity variable is 7.173 and the occupant density is 10.265 . Thus it can be said that the influence of humidity and occupant density variables in homes that do not meet the requirements can cause an influence or risk for the occurrence of TB disease approximately 7 times and 10 times greater than homes that have humidity and density of occupants fulfilling the requirements. The OR value after controlling for other variables and $95 \%$ confidence intervals (95\% CI), are shown in the Exp (B) and 95\% CI for Exp (B) columns in the last column of the table.

It is known that the OR value of the humidity variable is 7.173 and the value of $95 \% \mathrm{CI}$ is between 2.449-324.759. This means that the influence or risk of humidity in a house that does not meet the requirements $(<40 \%$ or $>60 \%)$ for non-sufferers of pulmonary tuberculosis is about 7 times greater than a house with eligible humidity (40-60\%) after controlling for variables other research. The OR value of the humidity variable in multivariate analysis (OR value $=7.173)$, is referred to as a controlled estimate.

Based on the value of $95 \% \mathrm{CI}$, it can be said that with a confidence interval of $95 \%$ the humidity of a house that does not meet the requirements can influence or risk the occurrence of pulmonary TB between 2,449-324,759 times greater than a house with lighting that meets the requirements after controlling for other research variables.

The OR value for the variable density of the control house dwellers is 10.265 and the value of $95 \% \mathrm{CI}$ is between $0.003-0.238$. This means that the effect or risk of occupant density in a non- 
eligible control house ( $<4 \mathrm{~m} 2$ / person) on the occurrence of pulmonary TB disease is about 10 times greater than a house with a density of eligible occupants ( $>4 \mathrm{~m} 2 /$ person) ..

OR values of occupant density variables in multivariate analysis $(\mathrm{OR}$ value $=10.265)$, are referred to as controlled estimates. This shows that if there is no control over other research variables, it can cause distortion estimates.

Based on the value of $95 \%$ CI can indicate that with a $95 \%$ confidence interval the density of residents in homes that do not meet the requirements can influence or risk the occurrence of pulmonary tuberculosis between 0.003 to 0.238 times greater than houses with density of occupants who meet the requirements after controlling for other research variables.

The results of measurements and observations of home windows are mostly closed tightly by using wooden boards, so that sunlight can not enter the house as a result the lighting in the house does not meet the requirements. The closing of the window by using wooden boards in a permanent manner was done because most of the respondents' livelihoods were as odd jobs workers $(23.2 \%)$, employees $(21.7 \%$ ), farmers and traders respectively $18.8 \%$, where the inhabitants left the house in during the day with the aim of maintaining the security of the house, they will return at dusk.

The community needs to make improvements / add some physical components of the house such as the addition of trellises for a sense of security from thieves and the replacement of wooden boards covering the window with glass so that sunlight can enter directly into the house, so that the lighting in the house meets the requirements.

The results of Dwi Ary Murtiningsih's research, Tri Pujikurniawan, Farid Setyo Nugroho (2014) showed that there was a relationship between ventilation area $(p=0,000)$, bedroom humidity ( $p$ $=0,000)$, and there was a relationship between sleep space lighting $(p=0,000)$ to the incidence of tuberculosis in Sukoharjo Public Health Center work area.

The results of Suparman, Miswan, and Muh. Andri (2018) showed that there was a risk factor for occupancy density with the incidence of pulmonary TB with a value $(\mathrm{OR})=14.222$, there was a broad risk factor for ventilation with a partial incidence of $\mathrm{TBC}$ with a value $(\mathrm{OR})=8.556$, and there were factors risk of floor type with the incidence of pulmonary $\mathrm{TB}$ with a value $(\mathrm{OR})=$ 5.958. So it was concluded that there was a risk factor for occupancy density with the incidence of pulmonary tuberculosis, there were extensive risk factors for ventilation with the incidence of pulmonary tuberculosis, and there were risk factors for floor type with pulmonary TB events.

Most people who are infected with M. Tuberculosis will not become sufferers of pulmonary tuberculosis. Only $10 \%$ of those infected will become TB sufferers (MOH, 2000). It can be assumed that people who are just not long enough to be exposed to the condition of pulmonary tuberculosis are less likely to develop pulmonary tuberculosis.

Housing construction is houses on stilts, walls and floors made of wood, however air circulation is still not maximized through the cracks in the floor and walls, so the humidity factor also has a significant effect on pulmonary tuberculosis. Humid atmosphere, helps the growth of microbes 
and the probability of transmission of pulmonary TB disease is greater. Tuberculosis bacteria can survive several hours in a dark and humid place because they do not get sunlight (ultraviolet light) which can kill the Tuberculosis bacteria (Dep. Kes RI, 2000).

The results of measurements of floor area compared to the number of occupants are eligible, the size of the house is large enough whose function is to store the harvest, so that the density of residential housing has no effect on pulmonary TB disease. Improvement of housing conditions and reduction of residential density can prevent the transmission of pulmonary tuberculosis. Dense residential housing causes increased transmission.

Occupancy density is the result of the area of the room with the number of residents in one house. The area of the house that is not comparable with the inhabitants will result in high density of residential occupancy (Jendra, 2015). In general, the assessment of occupant density using the minimum standard provisions, namely the density of occupants who meet health requirements is obtained from the quotient between the floor area with the number of occupants $\geq 9 \mathrm{~m}^{2}$ per person and the occupant density does not meet health cues if a quotient is obtained between the floor area and the number of occupants $<9 \mathrm{~m}^{2}$ per person.

The density of the inhabitants in a single house will give effect to its inhabitants. The area of the house that is not proportional to the number of inhabitants will cause congestion. This is unhealthy because besides causing a reduction in oxygen consumption, also if one family member is infected with an infectious disease, especially tuberculosis it will be easily transmitted to other family members, where an average sufferer can transmit it to 2-3 people in his house.

Based on the results of this study show that the significance values of lighting variables (0.04), humidity (0.004), and occupant density (0.33), which can be concluded that the lighting and humidity variables as well as the occupant density have a significant effect on Sufferers (TB) in South Barito Regency. While for the control (non-sufferers) of pulmonary tuberculosis, the variable humidity and occupant density had a significant effect on the $90 \%$ confidence level.

\section{CONCLUSION}

The physical environment of the housing of pulmonary tuberculosis sufferers in South Barito Regency does not generally meet the requirements of good lighting, ventilation, humidity and density of residents in the house. The physical environment that is not sufferers for lighting and occupant density is more qualified, but for ventilation and humidity is still dominant that does not meet the requirements. There is a significant influence on the level of $90 \%$ of the physical condition of the house from the lighting and humidity conditions as well as the density of its occupants towards sufferers of the disease Pulmonary tuberculosis in South Barito District, while for control (non-sufferers) pulmonary TB, humidity and occupant density variables have a significant effect after controlling for other research variables.

\section{REFERENCES}


Akbar, K., \& Perwitasari, D. (2013). Physical Condition of Houses and Behavior with Prevalence of Pulmonary Tuberculosis in DKI Jakarta, Banten and North Sulawesi Provinces. Litbangkes Media, 23 (4), 172-181

Ahmad Abdul Chamid. (2016). Application of the Topsis Method to Determine Priority of Home Conditions. Journal of Mechanical Engineering, Electrical and Computer Science 7 (2), 537-544.

Ardiansyah, M. 2012. Medical Surgery for Students. Diva Press. Jogjakarta

BPS of South Barito Regency. 2019. South Barito Regency in Figures.

Butiop, H. M.., Kandou, G. D., \& Palandeng, H. M. F. (2015). Relationship of Housemate, Ventilation Area, and Room Temperature with Lung Tuberculosis in Wori Village. Journal of Community and Tropical Medicine, III (4a), 241-248.

Bramantyo, A. Relationship of Child Nutrition Status, Education Level and Mother's Knowledge of Nutrition with the Success of Tuberculosis Treatment in Children in Pisangan Health Center. Jakarta: Thesis FK UPN Veteran. 2010

Dikromo, N. P., Antariksa, B., \& Nawas, A. (2011). Factors Associated to Success Tuberculosis Therapy of Co-infection of TB-HIV Patients in Pers Friendship Hospital, Jakarta-Indonesia. Indonesian Respiratory Journal, 31 (1), 14-21.

Djojodibroto, D. 2009. Resprology (Respiratory Medicine) .EGC. Jakarta

Dotulong, J. F. J., Sapulete, M. R., \& Kandou, G. D. (2015). Relationship between Age, Gender and Occupancy Density Risk Factors with the Occurrence of Tb Lung in Wori Village, Wori District. Journal of Community and Tropical Medicine, III (2), 57-65.

Dwi Ary Murtiningsih, Tri Pujikurniawan, Farid Setyo Nugroho. 2014. The Effect of Ventilation Area on the Incidence of Pulmonary Tuberculosis in the Work Area of Sukoharjo Public Health Center, Sukoharjo Regency. Faculty of Health Public Health Study Program. Muhammadiyah Surakarta university.

Fahreza, E. U., Waluyo, H., \& Novitasari, A. (2012). Relationship between the Physical Quality of the House and the Occurrence of Pulmonary Tuberculosis with a positive Acid Resistant Basil at the Semarang Community Lung Health Center. Muhammadiyah Medical Journal, 1 (2), 9-13.

Fibriana, L.P. 2018. Relationship Between Attitudes With Family Behavior About Prevention Of Tuberculosis Infectious Diseases.

http://www.dianhusada.ac.id/jurnalimg/jurper1-9-lin.pdf. Accessed on January 4, 2018

Fitriani, E. (2013). Risk Factors Related to Lung Tuberculosis. Unnes Journal of Public Health, 2 (1), 2-5.

Francis, C. 2011. Respiration treatments. Elangga. Jakarta 
Handoko, N.P. 2018. Relationship of Income Levels, Education, Knowledge, Attitudes of Prevention and Treatment Search, Prevention Practices and Search for Treatment with Tuberculosis at BBKPM Surakarta in 2010. www.akpergshwng.com/naspub_handoko.pdf. Approved dated January 4, 2018

Ministry of Health Republic of Indonesia. 2008. Basic Health Research Report 2007. Jakarta. 2010. Basic Health Research Report 2010. Jakarta.

Ministry of Health Republic of Indonesia. 2012. TB World Health Problems. Jakarta.

Ministry of Health Republic of Indonesia. 2007. National Guidelines for Tuberculosis Control Edition 2. Jakarta.

Ministry of Health Republic of Indonesia. 2009. Guidelines for Tackling Tuberculosis (TB). Jakarta.

Ministry of Health Republic of Indonesia. 2011. National Strategy for TB Control in Indonesia 2010-2014. Jakarta.

Ministry of Health Republic of Indonesia. 2014. National Guidelines for Controlling Tuberculosis (TB). Jakarta.

Kurniasari, N. 2008. Relationship between Knowledge and Attitudes of TB Patients with Regulations in the Treatment of Tuberculosis in UPTD Puskesmas Cibogo, Subang Regency in 2008.

Kusyogo, C., Ayu, R., Kurniasari, S., \& Cahyo, K. (2012). Risk Factors for Lung Tuberculosis in Baturetno District Wonogiri Regency. Indonesian Public Health Media, 11 (2), 198-204.

Media, Y. 2010. Community Knowledge, Attitudes and Behavior About Pulmonary Tuberculosis (TB) in Sungai Tarab District, TanahDatar Regency, West Sumatra Province in 2010.

Muaz, F. 2014. Factors that Affect the Occurrence of Positive Acid Resistant Tuberculosis in the District Health Clinic in Serang District Serang City in 2014. Thesis. Faculty of Health and Medicine, State Islamic University Syarif Hidayatulloh. Jakarta.

Sofiudin Dahlan. 2001. Statistics for Medicine and Health Edition 3. Publisher of Salemba Medika. Jakarta.

Sri Rahayu and Muhammad Ali Sodik. 2015. The Effect of Physical Environment on Houses with Lung TB Events in Lengkong District. Thesis. STIKES Surya Mitra Husada. Kediri. East Java

Suparman, Miswan, and Muh. Andri 2018. Risk Factors for the Quality of the Physical Environment of the Home Against the Occurrence of Pulmonary Tuberculosis in the Work Area of the Tomini Community Health Center. Faculty of Public Health, Muhammadiyah University, Palu. 
International Journal of Agriculture, Environment and Bioresearch

Vol. 4, No. 05; 2019

ISSN: $2456-8643$

Syofian Siregar. 2013. Quantitative Research Methods. Kencana Publisher Prenada Media Group. Jakarta.

Winslow, 1947. Health Goals for Housing. American Journal of Public Health and the Association. 